\title{
Characteristics of A Conducive Residential College Needed for Students with Disabilities in Public University: A Case Study at The University of Malaya, Kuala Lumpur, Malaysia
}

Mohd Faizul Ismail, Norizan Abdul Ghani, Sanopaka Endri

To Link this Article: http://dx.doi.org/10.6007/IJARBSS/v12-i1/12160

DOI:10.6007/IJARBSS/v12-i1/12160

Received: 13 November 2021, Revised: 16 December 2021, Accepted: 30 December 2021

Published Online: 20 January 2022

In-Text Citation: (Ismail et al., 2022)

To Cite this Article: Ismail, M. F., Ghani, N. A., \& Endri, S. (2022). Characteristics of A Conducive Residential College Needed for Students with Disabilities in Public University: A Case Study at The University of Malaya, Kuala Lumpur, Malaysia. International Journal of Academic Research in Business and Social Sciences, 12(1), 1365-1375.

\section{Copyright: @ 2022 The Author(s)}

Published by Human Resource Management Academic Research Society (www.hrmars.com) This article is published under the Creative Commons Attribution (CC BY 4.0) license. Anyone may reproduce, distribute, translate and create derivative works of this article (for both commercial and non0-commercial purposes), subject to full attribution to the original publication and authors. The full terms of this license may be seen at: http://creativecommons.org/licences/by/4.0/legalcode

Vol. 12, No. 1, 2022, Pg. $1365-1375$

Full Terms \& Conditions of access and use can be found at http://hrmars.com/index.php/pages/detail/publication-ethics 


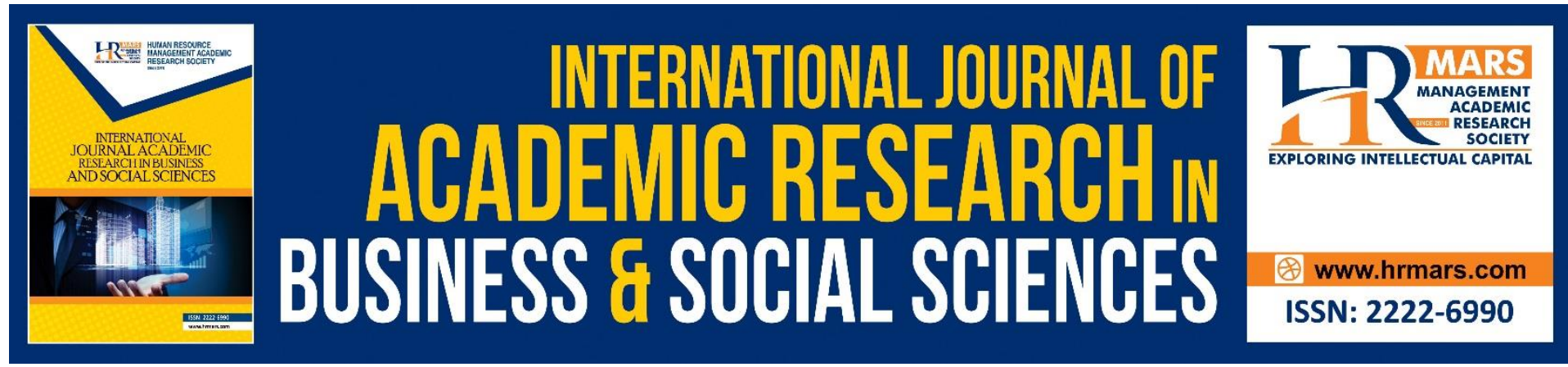

\title{
Characteristics of A Conducive Residential College Needed for Students with Disabilities in Public University: A Case Study at The University of Malaya, Kuala Lumpur, Malaysia
}

\author{
${ }^{1}$ Mohd Faizul Ismail, ${ }^{2}$ Norizan Abdul Ghani, ${ }^{3}$ Sanopaka Endri \\ 1,2Faculty of Applied Social Sciences, Universiti Sultan Zainal Abidin, Terengganu, Malaysia, \\ ${ }^{3}$ STISIPOL Raja Haji Tanjungpinang, Kepulauan Riau, Indonesia \\ Corresponding author: norizabd@unisza.edu.my
}

\begin{abstract}
A residential college in a public university is a secondary learning centre for undergraduates and also a place for them to rest. Developing a comfortable and conducive residential college can provide a better life quality to undergraduates. For students with disabilities (SWD), a residential college facility that is conducive is required for them to carry out their daily lives with ease. The weakness of providing a residential college that is unconducive will lead to discomfort among residents and this may give bad effects on the learning process and the life quality of disabled undergraduates hence compromising the concept of sustainability of the residential college. This research paper is conducted to explore the characteristics of a conducive residential college needed for students with disabilities from their perspective as residents of a residential college at the University of Malaya, Kuala Lumpur. This research used the qualitative method and data collected from 10 students with various disabilities. The results of this research have shown several characteristics of a residential college needed for students with disabilities which are security, comfortability, the environment around the college and basic facilities. This research can help policymakers and the higher management of Malaysian public universities in terms of the need for a conducive, inclusive and friendly residential college for students with disabilities to shape sustainable academic development.
\end{abstract} Keywords: Public Universities, Residential College, Students With Disabilities (Swd), Sustainable Development, Conducive Learning

\section{Introduction}

A residential college is an important component of a public university. Basically, a residential college is an accommodation facility provided by the university to students (Kim \& Lee, 2016). Student housing is classified as an important component provided by the higher education institution to help students expand their intellectual ability (Nasir \& Efendi, 2016). According to Najib and Sani (2012), the residential college is provided as an accommodation for students within their study period at higher education institutions in Malaysia. According to Cramm et al. (2014), a well-planned student housing facility can produce quality human capital to 
achieve the objectives of social unity and responsible citizenship. Among previous research Oke et al. (2017), it revealed that a good KPP promotes interaction between roommates with different backgrounds and courses and in turn can widen the knowledge of the student. Again, he said that facilities such as a study area or meeting place for academic discussion and social gathering provided in the KPP area can also promote informal intellectual activities outside the faculty. According to Darus (2006), even though a residential college is known as an accommodation place for students, it is also a place for student development activities to increase student personality. This is in line with a few residential college aims including creating an environment suitable for personal needs to achieve better performance (Abdullahi et al., 2017). This will drive excellence among undergraduates in their academics and the development of their personalities.

The integration of higher education at the global level has widened access for all categories of students including students with disabilities (SWD). This can be seen significantly in the increase in the number of SWDs who have enrolled in universities (Kim \& Lee, 2016) and it requires intensification of academic facilities and special accommodation in universities (Mugume \& Luescher, 2015). Therefore, the KPP or the hostel provided should be SWD friendly and conducive (Ajayi et al., 2015). According to Barnard-Brak et al. (2010), the term 'conducive' means providing the right conditions that can provide a stimulus to ensure a good one. Providing a conducive residential college is a challenge for the university. This is because the university should focus on the facilities that need to be provided to the SWDs. Abu Bakar Ahmed et al. (2014) explained that the facilities required by the SWDs are different for nondisabled students. The provision of people with disabilitie (PWD) friendly facilities is a preparation needed by disabilities students to live a more comfortable life. However, according to Abdullahi et al. (2017), most of the Educational institutions in the country are unable to meet the requirements for the SWDs and causes them to become less comfortable and in turn affect their academic performance. Therefore, this study was conducted to explore the characteristics of a conducive residential college needed by students with disabilities from their point of view as a student and a resident of a residential college in public universities.

\section{Background of The Study}

Education can be an important factor for people with disabilities (PWD) in achieving a better and quality life (Ferrer-i-Carbonell, 2005). The education policy that is inclusive in Malaysia has produced better education opportunities for SWDs. However, there are still many challenges that need to be overcome in the process of interpreting and applying policies from paper. The connotation of 'inclusive education' as expressed in the Salamanca Statement has brought about a paradigm shift in the way education is implemented from the aspect of special education to 'inclusive education', which provides opportunities for students with disabilities integration into the same education as other students (Haug, 2017). This article is recognised by the Convention on the Rights of Persons with Disabilities (CRPD) which endorses inclusive education as the best method to make the right to education effective for the disabled (Tah \& Mokhtar, 2016). Consensus and awareness among researchers, advocates as well as experts in the field of disability is increasing where they are able to identify the lack of facilities in meeting an equitable quality of life for the education of students with disabilities (Kuvalekar et al., 2015).

In the context of Malaysia, the government emphasises the right of students with disabilities to obtain equitable education from an early age equal to other communities. 
Article 28 of the Persons with Disabilities Act 2008 stipulates that children with special needs should be given the necessary assistance to encourage full and equal participation in their education. Based on current international best practices and national policies, the Malaysian government is committed to transferring more students with special needs towards inclusive education programs in order to improve the quality of their education as a whole. This commitment is in line with global trends towards inclusive education (Jelas \& Ali, 2014).

Therefore, residential college facilities and the disabled have a close relationship while in university. If a conducive residential college is not provided by the university, this group is unlikely to be able to live their lives as well as normal students. Therefore, in 2008, the Malaysian government has paid serious attention to the problems of the disabled (McBride, 2017). This effort has made the main campuses in the country undergo a change that is more PWD-friendly. These changes have affected the learning process of students hence improving the name of the public university in terms of conduciveness.

According to Buyung et al (2018), three main aspects need to be in the environment that need to be free from barriers which are function (functionality), safety (security) and comfort (comfort) of the space provided. In addition, the concept of a barrier-free environment (Barrier-Free Environment) has been introduced by urban planners in developed countries in providing a comfortable and safe environment for special groups (Winters, 2011). By emphasising the design principles that provide a comfortable environment for all groups, the disabled will experience convenience and comfort to live their lives while at the university.

Research on the provision of SWD facilities in the residential college should be considered by the university. The university needs to outline a specific guideline to create a conducive residential college that is able to provide comfort to students with disabilities and improve their quality of life. The provision of a conducive residential college will solve the problems that students with disabilities face while in the residential college. The provision of PWD-friendly facilities will help them to live their daily lives better.

\section{Objective of Research}

The objective of this research paper is to explore the characteristics of a conducive residential college needed by students with disabilities from their perspective as residents of a residential college at the University of Malaya, Kuala Lumpur.

\section{Research Methodology}

This study was conducted at the Za'ba residential college of the University of Malaya, Kuala Lumpur. This college was chosen as the scope of the study because it is a residential college specially allocated for PWDs at the University of Malaya. This study consisted of a total of 10 respondents that including seven males and three females with visual and physical disabilities. All respondents are undergraduate students aged 21 to 23 years.

This study uses a fully qualitative study using the case study method. Qualitative research is a research method that emphasises descriptive, inductive, grounded theory and the study of mankind on how they give meaning to their lives (Rozmi Ismail, 2015). According to Kamarul Azmi Jasmi (2012), a case study is a research technique conducted on a unity system either coming in the form of a programme or an event that is bound by a particular time, place or certain bonds.

In addition, this study also applies purposeful sampling techniques and snowball in selecting respondents. Through purposeful sampling, the criteria of the respondent must meet the conditions such as 1 . A student with a disability(s), University of Malaya; 2 . Lives at 
the Za'ba Residential College, University of Malaya; 3. Has lived at the Za'ba Residential College for at least one year; and 4. Aged 21 years and above.

To adhere to ethics, consent from the respondents was obtained in advance before the interview session was conducted. This method is used to facilitate the researcher to explore the experience and provide an opportunity for the respondents to share matters related to the issue of their residential colleges in their university.

This study used the N-Vivo application to analyse the data obtained. Through this application, the data obtained through in-depth interviews will be collected and re-translated into a full-text form (transcript). Each of the transcribed data forms themes that are related to characteristics of a conducive residential college. Therefore, it has met the objectives set in this study.

\section{Results}

All respondents were undergraduate students from different faculties (Table 1). The interview data obtained from the respondents were from the experiences they had as residents of residential colleges. The results of the interview show that some important features should be present in a residential college that has students with disabilities. The results of the study found that four characteristics are the priority for students with disabilities at the University of Malaya, Kuala Lumpur namely safety, college environment, comfort and basic facilities.

Table 1: Respondent's Profile

\begin{tabular}{cccc}
\hline Codename & Gender & Type of Disability & $\begin{array}{c}\text { Level } \\
\text { of Study }\end{array}$ \\
\hline SWD 1 & Male & Visual & Bachelor's Degree \\
SWD 2 & Male & Visual & Bachelor's Degree \\
SWD 3 & Male & Visual & Bachelor's Degree \\
SWD 4 & Male & Visual & Bachelor's Degree \\
SWD 5 & Male & Physical & Bachelor's Degree \\
SWD 6 & Male & Physical & Bachelor's Degree \\
SWD 7 & Male & Physical & Bachelor's Degree \\
SWD 8 & Female & Visual & Bachelor's Degree \\
SWD 9 & Female & Visual & Bachelor's Degree \\
SWD 10 & Female & Visual & Bachelor's Degree \\
\hline
\end{tabular}

Source: Study results from the researcher

\section{Security Features}

All respondents interviewed said safety features were important. Residential colleges that provide security to the occupants will be guaranteed their safety in carrying out their daily activities. SWD 1 who has a visual impairment states:

"Safety is important here. With the situation, not being able to see makes the risk of bad things happening is high. Safety at the college is very important to ensure my safety here." (SWD 1)

However, the safety that students with disabilities need is not just for their own. Security of valuables such as money, laptops, mobile phones and more is also important. The 
risk of losing valuables is high if safety at the college is not taken into consideration. SWD 3 expressed concern in the event of theft of goods at the residential college.

"I am also worried if my belongings are stolen such as laptops or mobile phones. These belongings are important to me here. I've also heard of people losing their laptops and money. This made me anxious and I was more alert. I always lock the room when I want to go out and sleep. The college and supervisors also regularly patrol. So I feel pretty safe." (SWD 3)

Students with disabilities express confidence in the university and college security. College staff and supervisors on duty will conduct inspections at the college level to ensure the safety of students with disabilities. SWD 7 shared his situation of living in a residential college for two years during his studies at the University of Malaya:

"I have lived here for 2 years. For me, the security provided by the college is very good. College staff often also do patrols and conduct building inspections and room keys. From the university security, there are also patrols during the day and night. With the steps taken by them, it makes me feel safe". (SWD 7)

The provision of security is an important element of a residential college. Failure to provide good security will create the risk of criminal cases. The role of college staff and security guards to ensure the safety of college residents is important. This is because the exposure of safety risks to students with disabilities is higher than other normal students. Continuous monitoring of these groups will ensure their safety. In addition, the provision of other safety facilities such as fire prevention, emergency routes, gathering places and others must be provided and function to prevent the occurrence of unwanted circumstances.

\section{Comfort Features}

Providing a comfortable room to rest is an important feature. In a residential college, comfortable living rooms will provide quality rest time for students. For students with disabilities, the comfort of the living room is important. They need a relatively large area to facilitate their daily movements. Room position, number of roommates and furniture layout are among the aspects to pay attention to.

In the interviews conducted, all informants stated that while in the room, they need to rest and study. Comfort is important to them. According to SWD 5 who was interviewed:

"I need a room with a relatively spacious space due to my physical disability to facilitate my move. In college, my room was reserved for 2 residents only and my roommates were among the disabled students as well. The room space is quite large and the arrangement of furniture in it is quite suited to my situation. Apart from that, the toilets provided are PWD -friendly and the toilets for my level can only be used by PWD students." (SWD 5).

In addition, some informants were also satisfied with the provision of accommodation at the college. The layout that has been done by the college and university provides facilities 
to students with disabilities. SWD 3 and SWD 9 expressed satisfaction with the provision of rooms in the residential college:

"For me, the comfort of the room is quite satisfactory. The floor of my room is on the lowest floor and this floor is for OKU students only. My room is quite large and the college has made arrangements in the room according to my suitability to move around. So it facilitates my activities in the room" (SWD 3).

"I value comfort when I'm in a college room. My condition of using a wheelchair requires quite a large amount of space. The college provided a room that quite suited my circumstances. So this makes it easier for me to move. My room is close to the exit of my floor making it easy for me to get out to go to class or the café. The toilet is also PWD friendly, so there is no problem for me to go to the toilet" (SWD 9).

The provision of facilities that provide comfort to students with disabilities is a challenge to the university. Each individual has his or her assessment of the comfort needed. The data showed that all informants were satisfied with the comfort of the room and the convenience of the environment. However, improvements need to be made to ensure that the comfort of students with disabilities is maintained.

\section{Features of the Residential College Environment}

A comfortable and conducive college environment can provide comfort to the residents to do leisure activities during their free time. A college environment that provides facilities such as an open space and recreation is important for students to reduce the stress of studying. Public recreational parks are held to provide recreational facilities based on the natural environment of an area or have certain characteristics to meet the physical and psychological needs of the community as well as a place of integration between races. Creating a conducive college environment will provide a range of benefits to students with disabilities. They can engage in healthy activities to fill their free time. SWD 4 states:

"The environment of this college is quite suitable for me. There is a relaxation area close to my room. If I wanted to take the afternoon breeze, I would go out and sit in the chairs provided. Recreation and sports facilities are also available. It's just that I don't think it's suitable for me to use. I just listen to other college friends who always play futsal" (SWD 4).

Conducive environmental conditions greatly benefit students with disabilities. Even if they have shortcomings, they are entitled to an environment that gives them comfort. SWD 6 and SWD 10 expressed satisfaction with the college environment:

"As long as I live in this college, I feel that the environment is quite satisfactory. My college area is in an area close to futsal fields, cafés and study halls for the disabled. So it's easy for me to go to the café to buy food and take a walk to catch the wind if I'm tired of being in the room" (SWD 6). 
"For me, the college environment is satisfying. There is a rest area near my room and there is no problem for me to go out to the streets in the college area. Leisure activities are quite limited because I am blind but I like to go out of the room and sit with friends outside the college building" (SWD 10).

A good college environment will affect the quality of life of students. Their involvement in doing some leisure activities after their study time will help them relieve stress while studying. Recreational activities whether passive or active are a routine that every student needs to do because individuals need to relax and fill their free time with certain activities. This is also needed by students with disabilities to ensure that they are free from any stress while studying and to ensure that their physical and mental health is maintained.

Basic Facility Features

The provision of basic facilities in residential colleges is one of the important aspects for students with disabilities. Basic facilities include disabled parking areas, transportation facilities, ATMs and CDMs, café and others that help students with disabilities. In the interviews conducted, the respondents stated that some of the basic amenity's requirements in the college environment area are needed by them. The features of these basic amenities will help their daily activities while in college. SWD 1 states:

"For me, other basic facilities like college transport services need to be improved. I hope the college provides van facilities more often and there is no need to make early bookings. Maybe even booking via a phone call can be done to make it easier for me to make a transport booking" (SWD 1).

Complete basic facilities will help students with disabilities while in their residential college. This feature will affect their comfort and even make the residential college a conducive college. In an interview conducted, SWD 7 stated:

"The facilities at this college can be said to be almost complete. Basic facilities in the hostel such as toilets, special study halls for the disabled and special paths for the disabled are provided. I just hope the transportation for students with disabilities is coordinated more orderly. To use the college van, I need to fill out a form first to make a reservation. University buses are available but I have to go outside the college fence to use the bus service" (SWD 7).

The involvement of colleges and universities to provide complete facilities is very important. The existing shortcomings need to be resolved immediately to ensure that students with disabilities enjoy the conducive facilities provided. Requests from students with disabilities are requests that help them to facilitate their daily activities. SWD 9 states the shortcomings that still exist in residential colleges, namely:

"I hope basic facilities such as ATM or CDM machines are provided in the college. In addition, other facilities provided by the college are satisfactory. From the pedestrian area to the café area is available close to the hostel. Toilet facilities are also suitable for use" (SWD 9). 
The characteristics of a conducive residential college are that it can provide convenience to its residents. Conducive facilities will help students with disabilities to manage themselves. If a college can fully provide conducive facilities, students with disabilities will be more independent and help facilitate their daily activities and give them more motivation to graduate from the university.

\section{Discussion and Recommendations}

The construction of a conducive residential college is a basic need for students with disabilities. Inline to create a sustainable residential college, various physical components need to be coordinated to have a positive impact on the college residents. This coordination will provide privileges to all students with disabilities studying at public universities who choose a residential college as their accommodation. The lack of conducive facilities that still exist needs to be improved to provide a comfortable and disabled-friendly college. A comfortable and PWD-friendly residential college will drive towards the realisation of sustainable residential colleges. It is in line with creating conducive public universities in the country. The Za'ba Residential College, University of Malaya has successfully provided conducive college facilities to students with disabilities. The provision of facilities and comfort to this group has shown the concern of the university to ensure the privileges and comfort of students with disabilities are guaranteed. Every public university needs to implement the features discussed to ensure that students with disabilities attain comfort while in the residential college.

In line with creating sustainable residential colleges, every university needs to be sensitive to the difficult situation of students with disabilities. Diverse disability conditions require varying facilities. This situation needs serious monitoring to ensure that there is no unknowingly discrimination against this group. By applying the concept of sustainability to residential colleges, the image of a comfortable and conducive life will be enjoyed by its residents. This situation also improves the quality of life of students with disabilities. The Ministry of Education needs to monitor the condition of residential colleges in universities from time to time. This monitoring will ensure that students with disabilities attain convenience and comfort while at the university. Providing facilities and comfort to students with disabilities will motivate them to succeed in their studies. In addition, the provision of a conducive residential college will open up many opportunities for people with disabilities to continue their studies and reduce their anxiety to be independent while at the university. The role of colleges and universities is also important which includes establishing a special task force that monitors the current situation of students with disabilities concerning the needs they need while in the residential college. This method will provide an opportunity for students with disabilities to convey their views and complaints directly to the college. Obtaining information directly from students with disabilities about their situation in residential colleges will help colleges and universities to overcome the existing shortcomings in the provision of conducive facilities.

\section{Conclusion}

Transformation of residential colleges needs to be done to ensure that students with disabilities can enjoy comfort while at university. The provision of facilities for the disabled in residential colleges will create a comfortable and conducive residence for all residents. University students, especially students with disabilities, need to enjoy the comfort of rest to ensure that the stress while studying can be reduced. This is important to ensure the quality 
of life of students with disabilities is more secure and to produce quality students. Awareness of all parties by instilling a caring attitude to students with disabilities can provide them with a more comfortable environment and help them to be competitive and become more independent like other normal students. This is also a step to motivate this group to continue to succeed.

\section{References}

Ahmed, A. B., Awad, Z. A. C., \& Yacoob, N. M. (2014). The response of accessibility infrastructures for PWD to National Disability Policies in higher institutions of developing countries: Case study of Ahmadu Bello University, Zarian and University of Malaya, Malaysia. Journal of Surveying, Construction and Property, 5(1), 1-16.

Abdullahi, I., Yusoff, W. Z., \& Gwamna, E. (2017). A review of physical and non-physical facilities' performance on student satisfaction in Northern Nigerian Universities. Social Science, 12(4), 600-608.

Ajayi, M., Nwosu, A., \& Ajani, Y. (2015). Students' satisfaction with hostel facilities in a federal university of technology, Akure, Nigeria. European Scientific Journal, 11(34), 402-415.

Darus, F. M. (2006). Budaya penyelenggaraan kemudahan kolej di kalangan mahasiswa: Kajian kes di Kolej Melati, Universiti Teknologi MARA, Shah Alam. In:National Student Development Conference (NASDEC) 2006, 8-9 August 2006, Kuala Lumpur, Malaysia.

Ferrer-i-Carbonell, A. (2005). Income and well-being: An empirical analysis of the comparison income effect. Journal of Public Economics, 89(5-6): 997-1019. SẸp.

Haug, P. (2017). Understanding inclusive education: Ideals and reality. Scandinavian Journal of Disability Research, 19(3): 206-217.

Jelas, Z. M., \& Ali, M. M. (2014). Inclusive education in Malaysia: Policy and practice. International Journal of Inclusive Education, 18(10): 991-1003.

Jasmi, K. A. (2012). Penyelidikan kualitatif dalam sains sosial. Kertas kerja kursus Penyelidikan Kualitatif Siri 1, Institut Pendidikan Guru Malaysia Kampus Temenggong Ibrahim, Johor, 28-29 Mac.

Khairuldin, W. M. K. F. W., Hassan, S. A., Anas, W. N. I. W. N., Mokhtar, W. K. A. W., \& Embong, A. H. (2020). Al-Takyif Al-Fiqhi and its application in Islamic research methodology. Journal of Critical Reviews, 7(7), 462-467.

Kim, W. H., \& Lee, J. (2016). The effect of accommodation on academicperformance of college students with disabilities. Rehabilitation Counselling Bulletin, 60(1), 40-50. https://doi.org/10.1177/0034355215605259

Kuvalekar, K., Kamath, R., Ashok, L., Shetty, B., Mayya, S., \& Chandrasekaran, V. (2015). Quality of life among persons with physical disability in udupi taluk: A cross sectional study. Journal of family medicine and primary care, 4(1), 69.

Najib, N. U. M., \& Sani, N. M. (2012). The effects of students' socio-physical backgrounds onto satisfaction with student housing facilities. Procedia-Social and Behavioral Sciences, 62, 64-74.

Mugume, T., \& Luescher, T. M. (2015). The politics of student housing: Student activism and representation in the determination of the user-price of a public-private partnership residence on a public university campus in South Africa. Journal of Student Affairs in Africa, 3(1), 1-17. https://doi.org/ 10.14426/jsaa.v3i1.89

Ismail, R. (2015). Metodologi penyelidikan: Teori dan praktis. Bangi: Penerbit Universiti Kebangsaan Malaysia. 
Tah, I. H. M., \& Mokhtar, K. A. (2016). Malaysia's ratification of the un convention on the rights of persons with disabilities (UN CRPD). International Journal of Business, Economics and Law, 11(4): 83-87.

Barnard-Brak, L., Lechtenberger, D., \& Lan, W. Y. (2010). Accommodation strategies of college students with disabilities. The Qualitative Report, 15(2), 411-429. Retrieved from http://www.nova.edu/ssss/QR/QR15-2/barnard-brak.pdf

UNESCO. Salamanca Statement. (2016). January 26. Retrieved from http://www.csie.org.uk/inclusion/unesco-salamanca.shtml.

Cramm, J. M., Lorenzo, T., \& Nieboer, A. P. (2014). Comparing Education, Employment, Social Support and Well-Being among Youth with Disabilities and Their Peers in South Africa. Applied Research in Quality of Life, 9(3): 517-524.

Oke, A. E., Aigbavboa, C. O., \& Raphiri, M. M. (2017). Students' satisfaction with hostel accommodation in higher education institutions. Journal of Engineering, Design and Technology, 15(5), 652-666. Retrieved from https://doi.org/10.1108/JEDT-04-20170036

Khairuldin, W. M. K. F. W., Anas, W. N. I. W. N., \& Embong, A. H. (2018). The Binding of Laws to Personal Opinion of Muftis in Malaysia. International Journal of Academic Research in Business and Social Sciences, 8(11), 522-529.

Buyung, M. R., Shafii, H., Yusoff, N. A., \& Rewahidayu, N. (2018). The Concept of Sustainable Residential College: A Study on the Provision of Facilities in the Public University Residential Colleges in Malaysia. International Journal of Academic Research in Business and Social Sciences, 8(4): 1167-1184.

Nasir, M. N. A., \& Efendi, A. N. A. E. (2017). Special education for children with disabilities in Malaysia: Progress and obstacles Muhamad Nadhir Abdul Nasir. Geografia-Malaysian Journal of Society and Space, 12(10): 78-87.

McBride, Y. (2017). Future of student housing: Meeting emerging student needs. On the Horizon, 25(3), 190-196. https://doi.org/10.1108/OTH-05-2017-0026.

Winters, J. V. (2011). Human capital, higher education institutions, and quality of life. Regional Science and Urban Economics, 41(5): 446-454. 